Article

\title{
Assessment of Ethyl Carbamate Contamination in Cachaça (Brazilian Sugar Cane Spirit)
}

\author{
Aline M. Bortoletto and André R. Alcarde* \\ Departamento de Agroindústria, Alimentos e Nutrição, Escola Superior de Agricultura "Luiz de Queiroz", \\ Universidade de São Paulo, Av. Pádua Dias 11, CP 9, 13418-900, Piracicaba, SP, Brazil; aline.bortoletto@usp.br \\ * Correspondence: andre.alcarde@usp.br; Tel.: +55-19-3447-8684
}

Academic Editor: Dimitrios Zabaras

Received: 18 July 2016; Accepted: 27 October 2016; Published: 31 October 2016

\begin{abstract}
Cachaça is a sugar cane spirit produced in Brazil. Ethyl carbamate (EC), a potential carcinogenic compound, may be present in cachaça above the limit established by law. The purpose of this study was to determine the concentration of ethyl carbamate in cachaças recently produced in Brazil in order to verify their compliance with the law. The concentration of ethyl carbamate was determined in 376 samples of cachaça through gas chromatography coupled to a mass spectrometer (GC-MS). The mean value of ethyl carbamate in the cachaças analyzed was $145 \mu \mathrm{g} / \mathrm{L}$, and $24 \%$ of them were not in compliancy with the law $(\mathrm{EC}<210 \mu \mathrm{g} / \mathrm{L})$. However, compared to previous studies, advances have been observed regarding the adjustment of cachaças to the legal limit. Cachaças produced in large distilleries through continuous column distillation presented a mean value of $200 \mu \mathrm{g} / \mathrm{L}$ of ethyl carbamate. Cachaças produced in small distilleries using pot still distillation presented a mean content of $74 \mu \mathrm{g} / \mathrm{L}$. Small producers have been more engaged in using good manufacturing practices to guarantee the quality of cachaças.
\end{abstract}

Keywords: sugar cane spirit; cachaça; chemical contamination; ethyl carbamate; law

\section{Introduction}

Cachaça is the typical and exclusive denomination of sugar cane spirit produced in Brazil, which can reach $38 \%-48 \% \mathrm{ABV}$ (alcohol by volume) at $20{ }^{\circ} \mathrm{C}$, obtained by distillation of fermented sugar cane juice [1].

The cachaça production process is not standardized, either in choosing the varieties of sugar cane, fermentation conditions, or in distillation equipment. Distillation may be carried out either in copper pot stills or in continuous columns. Aging cachaça in wooden barrels is optional.

Aside from presenting sensory properties such as an aromatic bouquet characteristic of sugarcane, flavors and pleasant aromas which satisfy the consumer, high quality cachaça must achieve certain chemical parameters so that it does not pose a health hazard if consumed moderately [2]. Low concentrations of contaminant compounds and acetic acid (the latter responsible for the acidity of cachaça) define the chemical quality of the spirit. The main compounds considered to be contaminants in cachaça are methanol, sec-butanol, $n$-butanol, ethyl carbamate, and copper.

Ethyl carbamate is a carcinogen in experimental animals, and is probably carcinogenic to humans (Group 2A) [3]. Its risk assessment may be conducted using the margin of exposure (MOE) approach, and the calculated lifetime cancer risk using the T25 method. The lower the MOE, the larger the risk for humans. The threshold of 10,000 is often used to define public health risks. The MOE from all alcoholic beverages was calculated to range between 400 and 2,466, indicating a great public health concern. The MOE for moderate drinkers of cachaça in Brazil ranged from 800 to 8,267. An even higher risk may exist for binge-drinkers of cachaça, with MOEs between 59 and 235. The lifetime cancer risk is at approximately 3 cases in 10,000, reaching 1 case per 1000 if alcoholic beverages with extremely 
high levels of ethyl carbamate were to be consumed on a daily basis. The whole population exposure from cachaça was calculated to be around 60 to $70 \mathrm{ng} / \mathrm{kg}$ bw/day. Nevertheless, the average ethyl carbamate exposure for daily drinkers of cachaça would be $400 \mathrm{ng} / \mathrm{kg}$ bw $/$ day. According to the risk assessment, ethyl carbamate poses a significant cancer risk for the alcohol-drinking population in Brazil, in addition to the risk associated with alcohol alone [4].

The risks for individual drinkers in Brazil appeared to be higher than the ones in Europe [5], which stated MOEs of 4,620 to 8,110 for consumers of alcoholic beverages in general, and specifically an MOE of 5,000 for consumers of spirits ( $125 \mathrm{~mL}$ daily).

In order to protect consumers' health, identity and quality standards have been established for cachaça in Brazil [1] which establish limits for non-alcoholic volatile components, as well as organic and inorganic contaminants that could be present in the spirits. In August 8th 2014, Brazilian law was revised for the maximum concentration of ethyl carbamate allowed in cachaça, $210 \mu \mathrm{g} / \mathrm{L}$ [6]. Before this date, the maximum value allowed was $150 \mu \mathrm{g} / \mathrm{L}$.

Several types of alcoholic beverage where the production process involves microbiological fermentative activity may contain ethyl carbamate [7]. The distillation process normally contributes to an enhancement of ethyl carbamate content in distilled beverages, because of the high temperature [8] and the presence of copper in the pot stills, which catalyzes the formation of this compound $[9,10]$. A positive correlation between copper and ethyl carbamate content in recently distilled sugar cane spirit has been reported. Concentrations of $0.8 \mathrm{mg} / \mathrm{L}$ of copper in the distillate fraction was enough to promote complete formation of ethyl carbamate, and higher levels of the element did not show an additional catalytic effect [11].

The presence of ethyl carbamate in alcoholic beverages is important due to the toxicological aspects, since it is a potentially carcinogenic compound [12], and therefore it should be kept at the minimum possible levels. Some countries, such as Canada, the United States, France, Germany, and Switzerland have specific laws to control the presence of ethyl carbamate in alcoholic beverages [13]. Besides being a public health problem, ethyl carbamate levels above $210 \mu \mathrm{g} / \mathrm{L}$ in cachaças may constitute a barrier to export.

Known precursors of ethyl carbamate are cyanide, urea, citrulline, and $N$-carbamyl phosphates $[8,13,14]$. The main pathway of ethyl carbamate formation in sugar cane spirits involves the cyanide ion formed by enzyme degradation of cyanogenic glycosides present in sugar cane. Cyanide is oxidized to cyanate, which in turn reacts with ethanol in the presence of the copper ion, forming ethyl carbamate [10]. A correlation between cyanate and ethyl carbamate formation in sugar cane spirits has been observed [15].

Urea is also a precursor of ethyl carbamate in alcoholic beverages, through the reaction with ethanol. Its presence in cachaça comes from urea-containing soil fertilizers, or from a supplementary source of nitrogen for sugar cane juice for fermentation. The formation of ethyl carbamate in wine has been associated with high concentrations of urea during fermentation [16]. Urea may also be formed by the degradation of arginine. The thermal decomposition of urea during distillation releases cyanic acid, a precursor of ethyl carbamate in spirits $[9,17]$. A strong correlation between the presence of urea in fermented juice and ethyl carbamate concentrations in sugar cane spirit has been observed [15]. Supplementation of sugar cane juice with urea caused the production of higher concentrations of ethyl carbamate in cachaças [18].

In addition to the precursors, the formation of ethyl carbamate in spirits depends on factors such as the type of microorganisms involved and by-products of their metabolism, fermentation temperature, distillation process, alcohol concentration, acidity, $\mathrm{pH}$, light, and period of storage after distillation [9,19-23].

Relatively high concentrations of ethyl carbamate are generally reported in cachaças [11,24-27]. A compilation of 13 studies, involving 536 samples, showed an average of $380 \mu \mathrm{g} / \mathrm{L}$ of ethyl carbamate in cachaças [4]. 
Conversely, the method of double distillation may significantly reduce the concentration of ethyl carbamate in distilled spirits. Since the boiling point of ethyl carbamate is $182-185^{\circ} \mathrm{C}$, the content of this compound in distilled beverages can successfully be monitored during a well-conducted distillation process. In whisky, for instance, it was observed that only $1 \%$ of the ethyl carbamate formed during the first distillation was distilled during the second distillation [9]. The "tail" distillate fraction accumulated $15 \%$ of the ethyl carbamate formed, and the stillage retained $84 \%$ of the ethyl carbamate present in the second distillation. In cachaça, double distillation promoted reduction of ethyl carbamate from $74 \%$ to $91 \%$ in the spirit [18]. Commercial cachaças presenting the lowest concentrations of ethyl carbamate (38 to $48 \mu \mathrm{g} / \mathrm{L}$ ) were double distilled [28]. Redistillation reduced the concentration of ethyl carbamate in 15 samples of commercial cachaça by up to $92.5 \%$ [29]. Double distillation reduced the concentration of ethyl carbamate in cachaça by 97\% [30]. In another study, Alcarde [31] reported reductions of this contaminant in sugar cane spirits ranging from $94.0 \%$ to $98.5 \%$, depending on the reflux rate during the second distillation in different types of still. In the state of Rio de Janeiro, 34 samples of cachaça collected from 28 producers were assessed, and the mean content of ethyl carbamate found was $160 \mu \mathrm{g} / \mathrm{L}$ [11]. The sample obtained by double distillation in a copper pot still presented only $17 \mu \mathrm{g} / \mathrm{L}$ of ethyl carbamate.

This study aimed to determine the concentration of ethyl carbamate in recently produced cachaças and to verify the evolution of cachaças in compliance with the national legislation since the investigation of ethyl carbamate (EC) concentration in sugar cane spirits started to be carried out in Brazil.

\section{Materials and Methods}

\subsection{Sample Collection}

During 2014 and 2015, 376 samples of cachaça were analyzed-165 in 2014, and 211 in 2015. The samples of spirits, purchased in the local markets, were produced in the Brazilian states of São Paulo (52\%), Minas Gerais (12\%), Ceará (9\%), Pernambuco (8\%), Paraíba (5\%), Mato Grosso do Sul (3\%), Goiás (2\%), Bahia (2\%), Rio Grande do Sul (2\%), Rio de Janeiro (2\%), Paraná (1\%), Santa Catarina (1\%), and Espírito Santo (1\%). The number of samples of each brand ranged from three to five, depending on their availability.

\subsection{Reagents and Standards}

Gas chromatography grade ethyl carbamate (Sigma-Aldrich, St. Louis, MO, USA) with purity $>99 \%$ was employed. High performance liquid chromatography grade ethanol (Merck, Kenilworth, NJ, USA) and ultrapure Milli-Q water (Millipore, Molsheim, France) were used for dilutions. The samples, standards, and solvents were previously filtered in Millex-HV filters (Millipore) with polyvinylidene difluoride (PVDF) membrane (13 mm diameter, $0.45 \mu \mathrm{m}$ pore size).

\subsection{Analytical Methods}

Samples with no previous treatment were analyzed for ethyl carbamate in a gas chromatograph coupled to a mass spectrometer, model GCMS-QP2010 Plus (Shimadzu, Kyoto, Japan), using selected ion monitoring (SIM) acquisition $(\mathrm{m} / \mathrm{z}=62)$, equipped with a chromatography capillary column with polar phase of esterified polyethylene glycol-HP-FFAP (Hewlett Packard-Free Fatty Acids and Phenols; $49 \mathrm{~m} \times 0.20 \mathrm{~mm} \times 0.33 \mu \mathrm{m}$ stationary phase film thickness). The temperatures of the injector and the detector interface were $230^{\circ} \mathrm{C}$ and $240{ }^{\circ} \mathrm{C}$, respectively. The following temperature program was used in the oven: starting with $90^{\circ} \mathrm{C}$ for $2 \mathrm{~min}$, increasing to $150{ }^{\circ} \mathrm{C}$ at a rate of $10{ }^{\circ} \mathrm{C} / \mathrm{min}$, followed by heating up to $220^{\circ} \mathrm{C}$ at a rate of $40{ }^{\circ} \mathrm{C} / \mathrm{min}$, and kept at this temperature for $2 \mathrm{~min}$. An aliquot of $2.0 \mu \mathrm{L}$ was injected using the splitless injection mode. Helium was used as the carrier gas at $30.0 \mathrm{~cm} / \mathrm{s}$ [30]. 
The quantification of ethyl carbamate was performed based on an external calibration curve $\left(C=174.5 \times \mathrm{A}-38.9 ; r^{2}=0.99\right)$ constructed using six points of standard concentrations. The detection limit $(\mathrm{DL}=1.6 \mu \mathrm{g} / \mathrm{L})$ and quantification limit $(\mathrm{QL}=5.1 \mu \mathrm{g} / \mathrm{L})$ were calculated based on the signal-to-noise ratio of the chromatograms [32].

\section{Results}

The median values of ethyl carbamate in cachaças analyzed in 2014 was $137 \mu \mathrm{g} / \mathrm{L}$, and the value for the cachaças analyzed in 2015 was $52 \mu \mathrm{g} / \mathrm{L}$ (Table 1). Nevertheless, a marked difference is noted between the mean values and the medians, indicating a skewed distribution of analytical results.

Table 1. Means and medians of the concentration of ethyl carbamate $(\mu \mathrm{g} / \mathrm{L})$ in samples of cachaça analyzed during the years 2014 and 2015.

\begin{tabular}{ccc}
\hline & Mean & Median \\
\hline 2014 (165 samples) & 171 & 137 \\
2015 (211 samples) & 124 & 52 \\
Total (376 samples) & 145 & 89 \\
\hline Mean = arithmetic mean; median = 50th percentile.
\end{tabular}

The maximum value observed was $975 \mu \mathrm{g} / \mathrm{L}$ for the cachaças analyzed in 2014, and $790 \mu \mathrm{g} / \mathrm{L}$ for those analyzed in 2015. The minimum value found was $<\mathrm{DL}$ for both years. According to the Brazilian legislation, 29\% of the samples analyzed in 2014 were not within the law (EC $<210 \mu \mathrm{g} / \mathrm{L}$ ). Regarding the cachaças analyzed in $2015,21 \%$ of the samples were not compliant with the law (Table 2).

Table 2. Percentage of samples of cachaça within the concentration ranges for ethyl carbamate ( $\mu \mathrm{g} / \mathrm{L})$.

\begin{tabular}{cccccc}
\hline \multicolumn{5}{c}{ Percentage of samples within the concentration range } & $\begin{array}{c}\text { Samples not in } \\
\text { for ethyl carbamate } \\
\text { compliance with law (\%) }\end{array}$ \\
\hline 2014 & $<150$ & $150-<210$ & $210-<300$ & $>300$ & $>210$ \\
(165 samples) & 55.7 & 15.8 & 15.2 & 13.3 & 28.5 \\
2015 & $<150$ & $150-<210$ & $210-<300$ & $>300$ & $>210$ \\
(211 samples) & 72.0 & 7.1 & 6.2 & 14.7 & 20.9 \\
Total & $<150$ & $150-<210$ & $210-<300$ & $>300$ & $>210$ \\
(376 samples) & 64.9 & 10.9 & 10.1 & 14.1 & 24.2 \\
\hline
\end{tabular}

Even with the increase of the maximum limit allowed for ethyl carbamate in cachaças (from 150 to $210 \mu \mathrm{g} / \mathrm{L}$ ) recently established by Brazilian law [6], a representative part of cachaças (24\%, Table 2) still present ethyl carbamate content above the maximum legal limit.

Cachaças produced in large distilleries through continuous column distillation (209 samples analyzed) presented a median value of $148 \mu \mathrm{g} / \mathrm{L}$ of ethyl carbamate (Table 3). Cachaças analyzed in 2014 (70 samples) produced in small distilleries using pot still distillation presented a median value of $73 \mu \mathrm{g} / \mathrm{L}$ of ethyl carbamate, and those analyzed in 2015 (97 samples) presented $15 \mu \mathrm{g} / \mathrm{L}$.

Table 3. Mean and median of the concentration of ethyl carbamate $(\mu \mathrm{g} / \mathrm{L})$ in cachaças produced from small distilleries (pot still distillation) and large distilleries (column distillation) during the years 2014 and 2015.

\begin{tabular}{ccccc}
\hline & \multicolumn{2}{c}{$\begin{array}{c}\text { Small distilleries } \\
\text { (pot still distillation) }\end{array}$} & \multicolumn{2}{c}{$\begin{array}{c}\text { Large distilleries } \\
\text { (column distillation) }\end{array}$} \\
\cline { 2 - 5 } & Mean & Median & Mean & Median \\
\hline 2014 & 129 & 73 & 200 & 160 \\
2015 & 34 & 15 & 201 & 120 \\
Total & 74 & 30 & 200 & 148 \\
\hline
\end{tabular}

Mean $=$ arithmetic mean; median $=50$ th percentile. 


\section{Discussion}

Since the analyses of ethyl carbamate in cachaça began, advances have been observed regarding the adjustment of these spirits to the legal limit (Table 4). In 2001, around $80 \%$ of cachaças were not in compliance with Brazilian law. In 2015, only 30\% of cachaças presented contents of ethyl carbamate above the maximum legal limit. Concerning the cachaças analyzed in the present study, $24 \%$ were not compliant with the law. Nevertheless, around $14 \%$ of the samples analyzed still presented ethyl carbamate contents above $300 \mu \mathrm{g} / \mathrm{L}$ (Table 2), which is much higher than the maximum legal limit of $210 \mu \mathrm{g} / \mathrm{L}$.

Table 4. Literature data on assessment of ethyl carbamate contamination in cachaça indicating the evolution of the percentage of samples not in compliance with Brazilian law over the years. LD: limit of detection.

\begin{tabular}{|c|c|c|c|c|c|c|c|}
\hline Reference study & $\begin{array}{c}\text { Sample } \\
\text { characterization }\end{array}$ & Collection sites & $N$ & $\underset{(\mu \mathrm{g} / \mathrm{L})}{\operatorname{Minimum}}$ & $\begin{array}{l}\text { Mean } \\
(\mu \mathrm{g} / \mathrm{L})\end{array}$ & $\underset{(\mu \mathrm{g} / \mathrm{L})}{\operatorname{Maximum}}$ & $\begin{array}{c}\text { Percentage } \\
\text { above } 210 \mu \mathrm{g} / \mathrm{L}\end{array}$ \\
\hline $\begin{array}{l}\text { Boscolo, } \\
2001[33]\end{array}$ & Brazilian market & Different states, Brazil & 84 & 42 & 904 & 5,589 & 84 \\
\hline $\begin{array}{l}\text { Andrade-Sobrinho } \\
\text { et al., } 2002 \text { [34] }\end{array}$ & $\begin{array}{l}\text { Column/pot still, } \\
\text { Brazilian market }\end{array}$ & Different states, Brazil & 126 & 13 & 770 & 5,700 & 76 \\
\hline $\begin{array}{l}\text { Bruno et al., } \\
2007 \text { [11] }\end{array}$ & $\begin{array}{l}\text { Column/pot still, } \\
\text { experimental and } \\
\text { Brazilian market }\end{array}$ & Rio de Janeiro State, Brazil & 34 & $<\mathrm{LD}$ & 160 & 714 & 35 \\
\hline $\begin{array}{l}\text { Baffa Júnior } \\
\text { et al., } 2007 \text { [24] }\end{array}$ & Brazilian market & Minas Gerais State, Brazil & 22 & 5 & 1,206 & 12,376 & 82 \\
\hline $\begin{array}{l}\text { Labanca et al., } \\
2008 \text { [25] }\end{array}$ & $\begin{array}{c}\text { Pot still, } \\
\text { Brazilian market }\end{array}$ & Minas Gerais State, Brazil & 71 & 33 & 893 & 2,609 & 91 \\
\hline $\begin{array}{l}\text { Nóbrega et al., } \\
2009 \text { [26] }\end{array}$ & $\begin{array}{c}\text { Pot still, } \\
\text { Brazilian market }\end{array}$ & Paraíba State, Brazil & 25 & 55 & 221 & 700 & 40 \\
\hline $\begin{array}{l}\text { Nóbrega et al., } \\
2011 \text { [27] }\end{array}$ & $\begin{array}{l}\text { Column/pot still, } \\
\text { Brazilian market }\end{array}$ & Pernambuco State, Brazil & 33 & $<\mathrm{LD}$ & 181 & 532 & 42 \\
\hline $\begin{array}{l}\text { Borges et al., } \\
2014 \text { [21] }\end{array}$ & $\begin{array}{c}\text { Pot still, } \\
\text { experimental }\end{array}$ & Minas Gerais State, Brazil & 30 & 44 & 141 & 320 & 27 \\
\hline $\begin{array}{l}\text { Present study, } \\
\text { samples } 2014\end{array}$ & Brazilian market & Different states, Brazil & 165 & $<\mathrm{LD}$ & 171 & 975 & 29 \\
\hline $\begin{array}{l}\text { Masson et al., } \\
2014 \text { [35] }\end{array}$ & $\begin{array}{c}\text { Pot still, } \\
\text { Brazilian market }\end{array}$ & Minas Gerais State, Brazil & 71 & 23 & 191 & 980 & 30 \\
\hline $\begin{array}{l}\text { Riachi et al., } \\
2014 \text { [36] }\end{array}$ & $\begin{array}{l}\text { Column/pot still, } \\
\text { Brazilian market }\end{array}$ & Different states, Brazil & 657 & $<\mathrm{LD}$ & 257 & 1,206 & 42 \\
\hline $\begin{array}{l}\text { Present study, } \\
\text { samples } 2015\end{array}$ & Brazilian market & Different states, Brazil & 211 & $<\mathrm{LD}$ & 124 & 790 & 21 \\
\hline $\begin{array}{c}\text { Bortoletto and } \\
\text { Alcarde , } 2015 \text { [37] }\end{array}$ & Brazilian market & Different states, Brazil & 268 & 4 & 221 & 1,365 & 39 \\
\hline
\end{tabular}

Earlier studies have indicated that most of the cachaças produced in Brazil presented a higher ethyl carbamate content than the upper permitted limit of $210 \mu \mathrm{g} / \mathrm{L}$. Ethyl carbamate contents ranging from 42 to $5,589 \mu \mathrm{g} / \mathrm{L}$, with a mean value of $904 \mu \mathrm{g} / \mathrm{L}$, were observed in 84 samples of cachaça from several regions of Brazil [33]. Only 16\% of these samples presented ethyl carbamate contents below the maximum legal limit of $210 \mu \mathrm{g} / \mathrm{L}$. Contents ranging from 13 to 5,700 $\mu \mathrm{g} / \mathrm{L}$ of ethyl carbamate, with a mean value of $770 \mu \mathrm{g} / \mathrm{L}$, were determined in 126 samples of cachaça (63 from the Southeast Region, 39 from the Northeast Region, 22 from the South Region, and 2 from the Midwest Region of Brazil) [34]. Only $24 \%$ of these samples had ethyl carbamate contents below $210 \mu \mathrm{g} / \mathrm{L}$.

Other studies in Brazil also found high contents of ethyl carbamate in commercial sugar cane spirits and cachaças. Twenty-two brands of cachaça from Zona da Mata Mineira, in the state of Minas Gerais, registered contents of this contaminant ranging from 5 to $12,376 \mu \mathrm{g} / \mathrm{L}$, with a mean value of 1,206 $\mu \mathrm{g} / \mathrm{L}$ [24]. Among the 22 samples analyzed, only four (18\%) presented ethyl carbamate contents below $210 \mu \mathrm{g} / \mathrm{L}$. Ethyl carbamate content above the maximum legal limit was found in $35 \%$ of 34 samples of cachaça collected from 28 different producers in the state of Rio de Janeiro [11]. The content of ethyl carbamate ranged from 33 to 2,609 $\mu \mathrm{g} / \mathrm{L}$, with a mean value of $893 \mu \mathrm{g} / \mathrm{L}$, in 71 samples of sugar cane spirits produced in the state of Minas Gerais [25]. Only $9 \%$ of the samples presented contents below the maximum legal limit. The contents of ethyl carbamate ranged from 55 to 
$700 \mu \mathrm{g} / \mathrm{L}$, with a mean value of $221 \mu \mathrm{g} / \mathrm{L}$, in 25 cachaças from 19 different distilleries in the state of Paraíba; $40 \%$ of the samples exceeded the legal limit [26]. A study with 33 cachaças from 19 different distilleries in the state of Pernambuco found that the maximum content of ethyl carbamate in the samples analyzed was $532 \mu \mathrm{g} / \mathrm{L}$, and 14 samples (42\%) exceeded the limit of $210 \mu \mathrm{g} / \mathrm{L}$ [27].

A compilation of 24 studies showed that $42 \%$ of 657 cachaças analyzed presented ethyl carbamate contents above $210 \mu \mathrm{g} / \mathrm{L}$ [36]. A similar value (39\%) was found analyzing ethyl carbamate content in 268 cachaças produced all over Brazil [37]. Ethyl carbamate levels were determined in 30 cachaças produced in the State of Minas Gerais by spontaneous fermentation or selected Saccharomyces cerevisiae strains, and only eight samples (27\%) presented ethyl carbamate contents above $210 \mu \mathrm{g} / \mathrm{L}$ [21]. The ethyl carbamate concentrations in samples of cachaça produced in the state of Minas Gerais varied from 22 to $980 \mu \mathrm{g} / \mathrm{L}$, and $70 \%$ of the samples analyzed had concentrations equal to or below the maximum legal limit [35]. A similar value was found in the present study.

In the present study, cachaças produced in large distilleries through continuous column distillation presented concentrations of ethyl carbamate (median $148 \mu \mathrm{g} / \mathrm{L}, N=209$ ) higher than those produced in small distilleries (median $30 \mu \mathrm{g} / \mathrm{L}, N=167$ ). These results show the concern of the small producers in decreasing the level of the contaminant in cachaça using good manufacturing practices (GMP) in order to guarantee the quality of the production process and aiming to control the quality of the spirit.

Cachaças from different regions of Brazil presented a mean value of $930 \mu \mathrm{g} / \mathrm{L}$ for those distilled in columns (69 samples) and $630 \mu \mathrm{g} / \mathrm{L}$ for those distilled in pot stills (34 samples) [34]. In the state of Rio de Janeiro, 32 samples of cachaça collected from 28 producers were assessed, and the mean content of ethyl carbamate found was $160 \mu \mathrm{g} / \mathrm{L}$ [11]. The 10 samples obtained by distillation in a continuous column presented a mean value of $320 \mu \mathrm{g} / \mathrm{L}$ of ethyl carbamate, and the 17 samples obtained by simple distillation in a copper pot still presented a mean value of $145 \mu \mathrm{g} / \mathrm{L}$ ethyl carbamate. The five samples obtained by distillation in a stainless steel pot still with a coiled copper pipe presented a mean value of $90 \mu \mathrm{g} / \mathrm{L}$ of the contaminant.

In a literature review (comprising 13 studies) on the occurrence of ethyl carbamate in cachaças purchased in the Brazilian market, a total of 536 analytical results provided an average of $380 \mu \mathrm{g} / \mathrm{L}$ of the contaminant in the samples analyzed [4]. However, taking into account the weighting of data based on the production of cachaças in pot still (38\%) and column still (62\%), the average content of this contaminant was $450 \mu \mathrm{g} / \mathrm{L}$. Column still cachaça (mean $490 \mu \mathrm{g} / \mathrm{L}, N=101$ ) had a higher content of ethyl carbamate than pot still cachaça $(380 \mu \mathrm{g} / \mathrm{L}, N=275)$.

Thirty-three cachaças (13 from pot stills and 20 from column stills) produced in the state of Pernambuco presented averages of $60 \mu \mathrm{g} / \mathrm{L}$ for pot still cachaças, and $257 \mu \mathrm{g} / \mathrm{L}$ for those distilled in columns [27].

According to the compilation of 24 studies [35], single distilled pot still cachaças ( 35 samples) presented an average concentration of ethyl carbamate of $75 \mu \mathrm{g} / \mathrm{L}$. On the other hand, the average concentration of ethyl carbamate in cachaças distilled in continuous columns (214 samples) was $493 \mu \mathrm{g} / \mathrm{L}$.

The risks for individual drinkers in Brazil appeared to be higher than the ones in Europe [38]. The evaluation of levels of ethyl carbamate in European spirits during the years 2010-2012 indicated that $14 \%$ of the analytical results were above the target value of $1 \mathrm{mg} / \mathrm{L}$ indicated in Commission Recommendation 2010/133/EU. The highest occurrence levels of ethyl carbamate were found in the group "spirits made from stone fruits" (mean $698 \mu \mathrm{g} / \mathrm{L} ;$ median $214 \mu \mathrm{g} ; \mathrm{N}=1945$ ). Although the mean occurrence was below the target value of $1 \mathrm{mg} / \mathrm{L}, 15 \%$ of the results were above this value.

In the group "spirits not from fruit" the mean occurrence was $55 \mu \mathrm{g} / \mathrm{L}$ (median $=38 \mu \mathrm{g} / \mathrm{L}$; $N=20$ ), which is lower than in the previous group by almost a factor of 13 . The mean occurrence in the subgroup "rum" was $65 \mu \mathrm{g} / \mathrm{L}(N=4)$. In the subgroup "vodka and vodka-like spirits", a mean occurrence of $66 \mu \mathrm{g} / \mathrm{L}$ (median $=50 ; N=10$ ) was observed. The subgroup "whisky" presented a mean of $30 \mu \mathrm{g} / \mathrm{L}$ (median $=20 \mu \mathrm{g} / \mathrm{L} ; N=6$ ). All of the analytical results for the group "spirits not from fruit" were below the target value of $1 \mathrm{mg} / \mathrm{L}$. 
Considering the group "spirits not from fruit", in which cachaça could be included, the mean occurrence of $145 \mu \mathrm{g} / \mathrm{L}$ (median $=89 \mu \mathrm{g} / \mathrm{L} ; N=376$ ) found in the present study was roughly three times the mean value presented by rum, vodka, and whisky.

\section{Conclusions}

The quality of cachaça depends on two main factors: sensory properties agreeable to consumers, and chemical composition that does not pose risks to their health. Among the 377 samples of cachaça analyzed during the years 2014 and 2015, 27.8\% were not in compliance with the limit of ethyl carbamate established by Brazilian law. Furthermore, based on the high standard deviation among the samples analyzed, cachaça presents a great heterogeneity concerning the concentration of the contaminant in the spirit. This suggests that producers continue to face difficulties in using GMPs aiming to ensure consistency in the production process. However, since the analyses of this contaminant have started, advances have been observed regarding the adjustment of ethyl carbamate levels in cachaças to the legal limit.

Acknowledgments: The authors are grateful to Fundação de Amparo à Pesquisa do Estado de São Paulo (FAPESP) for the financial support of this research.

Author Contributions: A.M.B. and A.R.A. conceived and designed the experiments; A.M.B. performed the experiments; A.M.B. and A.R.A. analyzed the data and wrote the paper.

Conflicts of Interest: The authors declare no conflict of interest.

\section{References}

1. BRASIL. Ministério da Agricultura, Pecuária e Abastecimento. Instrução Normativa no 13 , de 29 de junho de 2005. Available online: http://extranet.agricultura.gov.br/sislegis-consulta/consultarLegislacao.do? operacao=visualizar\&id=12386 (accessed on 14 June 2016).

2. Alcarde, A.R. Cachaça: Ciência, Tecnologia e Arte; Edgard Blucher: São Paulo, Brasil, 2014; pp. 9-10.

3. IARC (International Agency for Research on Cancer). Monographs on the Evaluation of Carcinogenic Risks to Humans. Alcoholic Beverage Consumption and Ethyl Carbamate (Urethane). 2007, Volume 96, pp. 1-5. Available online: http://monographs.iarc.fr/ENG/Monographs/vol96/mono96.pdf (accessed on 28 October 2016).

4. Lachenmeier, D.W.; Lima, M.C.P.; Nóbrega, I.C.C.; Pereira, J.A.P.; Kerr-Corrêa, F.; Kanteres, F. Cancer risk assessment of ethyl carbamate in alcoholic beverages from Brazil with special consideration to the spirits cachaça and tiquira. BMC Cancer 2010, 10, 266. [CrossRef] [PubMed]

5. EFSA (European Food Safety Authority). Opinion of the Scientific Committee on a request from EFSA related to a harmonised approach for risk assessment of substances which are both genotoxic and carcinogenic. EFSA J. 2005, 282, 1-31.

6. BRASIL. Ministério da Agricultura, Pecuária e Abastecimento. Instrução Normativa $n^{\circ} 28$, de 8 de agosto de 2014. Available online: http://www.lex.com.br/legis_25819224_INSTRUCAO_NORMATIVA_N_28_DE_ 8_DE_AGOSTO_DE_2014.aspx (accessed on 14 June 2016).

7. Ough, C.S. Ethylcarbamate in fermented beverages and foods. I. Naturally occurring ethylcarbamate. J. Agric. Food Chem. 1976, 24, 323-328. [CrossRef] [PubMed]

8. Stevens, D.F.; Ough, C.S. Ethyl carbamate formation: Reaction of urea and citrulline with ethanol in wine under low to normal temperature conditions. Am. J. Enol. Vitic. 1993, 44, 309-312.

9. Riffkin, H.L.; Wilson, R.; Howie, D.; Muller, S.B. Ethyl carbamate formation in the production of pot still whisky. J. Inst. Brew. 1989, 95, 115-119. [CrossRef]

10. Aresta, M.; Boscolo, M.; Franco, D.W. Copper (II) catalysis in cyanide conversion into ethyl carbamate in spirits and relevant reactions. J. Agric. Food Chem. 2001, 49, 2819-2824. [CrossRef]

11. Bruno, S.N.F.; Vaitsman, D.S.; Kunigami, C.N.; Brasil, M.G. Influence of the distillation processes from Rio de Janeiro in the ethyl carbamate formation in Brazilian sugar cane spirits. Food Chem. 2007, 104, 1345-1352. [CrossRef]

12. Zimmerli, B.; Schlatter, J. Ethyl carbamate: Analytical methodology, occurrence, formation biological activity and risk assessment. Mutat. Res. 1991, 259, 325-350. [CrossRef] 
13. EFSA - European Food Safety Authority. Ethyl carbamate and hydrocyanic acid in food and beverages. Eur. Food Saf. Author. J. 2007, 551, 1-44.

14. Ough, C.S.; Crowell, E.A.; Gutlove, B.R. Carbamyl compound reactions with ethanol. Am. J. Enol. Vitic. 1988, 39, 239-242.

15. Ohe, T.H.K.; Silva, A.A.; Rocha, T.S.; Godoy, F.S.; Franco, D.W. A fluorescence-based method for cyanate analysis in ethanol/water media: Correlation between cyanate presence and ethyl carbamate formation in sugar cane spirit. J. Food Sci. 2014, 79, 1950-1955. [CrossRef] [PubMed]

16. Ough, C.S.; Crowell, E.A.; Mooney, L.A. Formation of ethyl carbamate precursors during grape juice (Chardonnay) fermentation. I. Addition of amino acids, urea, and ammonia: Effects of fortification of intracellular and extracellular precursors. Am. J. Enol. Vitic. 1988, 39, 243-249.

17. Lachenmeier, D.W.; Schehl, B.; Kuballa, T.; Frank, W.; Senn, T. Retrospective trends and current status of ethyl carbamate in German stone-fruit spirits. Food Addit. Contam. 2005, 22, 397-405.

18. Bortoletto, A.M.; Silvello, G.C.; Alcarde, A.R. Chemical and microbiological quality of sugar cane juice influences the concentration of ethyl carbamate and volatile congeners in cachaça. J. Inst. Brew. 2015, 121, 251-256. [CrossRef]

19. Santiago, W.D.; Cardoso, M.G.; Duarte, F.C.; Saczk, A.A.; Nelson, D.L. Ethyl carbamate in the production and aging of cachaça in oak (Quercus sp.) and amburana (Amburana cearensis) barrels. J. Inst. Brew. 2014, 120, 507-511.

20. Battaglia, R.; Conacher, H.B.S.; Page, B.D. Ethyl carbamate (urethane) in alcoholic beverages and foods: A review. Food Addit. Contam. 1990, 7, 477-496. [CrossRef] [PubMed]

21. Borges, G.B.L.; Gomes, F.C.O.; Badotti, F.; Silva, A.L.D.; Machado, A.M.R. Selected Saccharomyces cerevisiae yeast strains and accurate separation of distillate fractions reduce the ethyl carbamate levels in alembic cachaças. Food Contr. 2014, 37, 380-384. [CrossRef]

22. Zacaroni, L.M.; Cardoso, M.G.; Santiago, W.D.; Gomes, M.S.; Duarte, F.C.; Nelson, D.L. Effect of light on the concentration of ethyl carbamate in cachaça stored in glass bottles. J. Inst. Brew. 2015, 121, 238-243. [CrossRef]

23. Mendonça, J.G.P.; Cardoso, M.G.; Santiago, W.D.; Rodrigues, L.M.A.; Nelson, D.L.; Brandão, R.M.; Silva, B.L. Determination of ethyl carbamate in cachaças produced by selected yeast and spontaneous fermentation. J. Inst. Brew. 2016, 122, 63-68. [CrossRef]

24. Baffa Júnior, J.C.; Soares, N.F.F.; Pereira, J.M.A.T.K.; Melo, N.R. Ocorrência de carbamato de etila em cachaças comerciais da região da Zona da Mata Mineira-MG. Alim. Nutr. 2007, 18, 371-373.

25. Labanca, R.A.; Glória, M.B.A.; Afonso, R.J.C.F. Determinação de carbamato de etila em aguardentes de cana por CG-EM. Quim. Nova 2008, 31, 1860-1864. [CrossRef]

26. Nóbrega, I.C.C.; Pereira, J.A.P.; Paiva, J.E.; Lachenmeier, D.W. Ethyl carbamate in pot still cachaças (Brazilian sugar cane spirits): Influence of distillation and storage conditions. Food Chem. 2009, 117, 693-697. [CrossRef]

27. Nóbrega, I.C.C.; Pereira, J.A.P.; Paiva, J.E.; Lachenmeier, D.W. Ethyl carbamate in cachaça (Brazilian sugarcane spirit): Extended survey confirms simple mitigation approaches in pot still distillation. Food Chem. 2011, 127, 1243-1247. [CrossRef] [PubMed]

28. Nagato, L.A.F.; Silva, O.A.; Yonamine, M.; Penteado, M.V.C. Quantitation of ethyl carbamate (EC) by gas chromatography and mass spectrometric detection in distilled spirits. Alimentaria 2000, 311, 31-36.

29. Galinaro, C.A.; Franco, D.W. Formação de carbamato de etila em aguardentes recém-destiladas; proposta para seu controle. Quim. Nova 2011, 34, 996-1000. [CrossRef]

30. Bortoletto, A.M.; Alcarde, A.R. Congeners in sugar cane spirits aged in casks of different woods. Food Chem. 2013, 139, 695-701. [CrossRef] [PubMed]

31. Alcarde, A.R.; Souza, L.M.; Bortoletto, A.M. Ethyl carbamate kinetics in double distillation of sugar cane spirit. Part 2: Influence of type of pot still. J. Inst. Brew. 2012, 118, 352-355. [CrossRef]

32. Currie, L.A. International recommendations offered on analytical detection and quantification concepts and nomenclature. Anal. Chim. Acta 1999, 391, 103-134. [CrossRef]

33. Boscolo, M. Caramelo e carbamato de etila em aguardente de cana. Ocorrência e quantificação. Doctoral Thesis, Universidade de São Paulo, São Carlos, Brasil, 2001.

34. Andrade-Sobrinho, L.G.; Boscolo, M.; Lima-Neto, B.S.; Franco, D.W. Carbamato de etila em bebidas alcoólicas (cachaça, tiquira, uísque e grapa). Quim. Nova 2002, 25, 1074-1077. [CrossRef] 
35. Masson, J.; Cardoso, M.G.; Zacaroni, L.M.; Anjos, J.P.; Santiago, W.D.; Machado, A.M.R.; Saczk, A.A.; Nelson, D.L. GC-MS analysis of ethyl carbamate in distilled sugar cane spirits from northern and southern regions of Minas Gerais. J. Inst. Brew. 2014, 120, 516-520. [CrossRef]

36. Riachi, L.G.; Santos, A.; Moreira, R.F.A.; de Maria, C.A.B. A review of ethyl carbamate and polycyclic aromatic hydrocarbon contamination risk in cachaça and other Brazilian sugarcane spirits. Food Chem. 2014, 149, 159-169. [CrossRef] [PubMed]

37. Bortoletto, A.M.; Alcarde, A.R. Assessement of chemical quality of Brazilian sugar cane spirits and cachaças. Food Contr. 2015, 54, 1-6. [CrossRef]

38. EFSA (European Food Safety Authority). Evaluation of Monitoring Data on Levels of Ethyl Carbamate in the Years 2010-2012; EFSA supporting publication 2014:EN-578; EFSA: Parma, Italy, 2014.

(C) 2016 by the authors; licensee MDPI, Basel, Switzerland. This article is an open access article distributed under the terms and conditions of the Creative Commons Attribution (CC-BY) license (http:/ / creativecommons.org/licenses/by/4.0/). 